\title{
Economic Globalization and Economic Performance Dynamics: Some New Empirical Evidence from Nigeria
}

\author{
Nahanga Verter \\ Department of Regional and Business Economics, Mendel University in Brno \\ Email: xverter@mendelu.cz \\ Christian Nedu Osakwe \\ Faculty of Management and Economics, Tomas Bata University in Zlin \\ Email: osakwe@fame.utb.cz
}

\section{Doi:10.5901/mjss.2015.v6n1p87}

\begin{abstract}
The study focuses on the macro-economic impact of leading economic globalization indicators on the Nigerian economy, during the period from 1980 to 2012. The findings from this study lend credence to the FDI-led growth hypothesis in developing economies. Moreover, migrants' remittances inflow was found to be positively associated with economic performance, albeit in the short-run only. In contrast, the KOF dimension of economic globalization index (ECGI) was found to have an adverse effect on economic performance in the long-run and equally showed proof of a negative relationship in the short-run even though it was statistically insignificant. Similarly, real effective exchange rate and trade openness were found to be statistically insignificant in the short-run and long-run. Policy makers in Nigeria should endeavour to create robust legislation and credible institutional frameworks that would not only encourage more capital flows into the shores of Nigeria, but also would protect the country's 'interest' in the midst of ongoing economic globalization.
\end{abstract}

Keywords: economic growth, ARDL approach, cointegration, FDI, development;

\section{Introduction}

The worldwide interconnectedness of countries especially after the 2nd World War has been changing the socioeconomic and political landscapes in different nations in recent time, thanks to globalization. While most countries, institutions and scholars across the continents have embraced globalization, some are still sceptical about it. The integration of various national economies through trade liberalization, migration, technology transfers and governance have come with both benefits and challenges. It is widely presumed that, developed countries are the most beneficial of trade liberalization and deregulation as they have a greater share of the world trade, technical know-how, manufacturing and finance.

International trade (export and import of goods and services), foreign direct investment (FDI) and migrants' remittances are vital tools for accelerating rapid economic performance in many developing countries that are poised to develop. However, many poor countries have not been able to benefit sufficiently from globalization partly due to their inability to compete favourably with advanced economies at the global stage due to inadequate resources, insufficient utilization of its resources, imbalances of world trade policies and agreements.

In the case of Nigeria, looking at the current situation; the country is still underdeveloped despite enormous resources at her disposal and the opportunities brought by globalization. Scholars widely claim that high level of corruption, export monoculture, and the inability to attract more foreign direct investments are among the causes of low real GDP per capita or economic performance in the country.

Can Nigeria survive without economic globalization? What is the country doing to tap from the opportunities inherent in economic liberalization? Some scholars (Osabuohien, 2007; Loto, 2011; Ajayi and Atanda, 2012) have attempted to look at the macroeconomic benefits as well the costs posed by some economic globalization dynamics on the state of affairs of the Nigerian economy. However, empirical results so far from these findings have remained inconclusive. More so, to the best of our knowledge, none of these research works have fully incorporated all the variables of interest within this present study to verify the effect of economic globalization on real GDP per capita in recent decades. This is one of the motivating factors behind this paper. It also makes our work not only relevant but also novel in a way considering the study's chosen methodology (ARDL approach to cointegration). 
The major objective of this article is to empirically analyse the relationship between some leading economic globalization indicators and economic performance, by using the aforementioned methodology. See figure 1 for an illustration of these leading indicators in Nigeria

\section{Economic Globalization Dynamics}

It is important to state that globalization within its widest context has several meanings and depending on the context of usage. Unarguably, there is no universally acceptable definition of globalization as different scholars define it based on their understanding and at a certain point in time that makes the meanings far from being consistent.

One of the strongest and first significant things about globalization was the internationalization of trade in the 15th century. However, what was called international trade then was nothing but the extension overseas of European and American interests (Walter, 1972). According to Ocampo and Martin (2003), globalization is the growing influence that exerts on the local and national levels by financial, economic, environmental, political, social, and cultural processes that are interconnected in scope.

Todaro and Smith (2011) see globalization as the process by which world economy becomes more interconnected, leading to a global economy and, increasingly, global economic policy making, emerging of "global culture," in which the masses consume similar goods and services across national borders.

Nowadays, due to economic integration within and outside continents, this had drastically reduced barriers to foreign trade and inflows of foreign capitals inform of FDI, international remittances and foreign aid. Economic "globalization" is a historical process that results in human innovation and technological progress (IMF, 2008).

The integration and expansion of world trade and financial flows through the abolition or reduction of trade barriers such as tariffs, quotas and liberalize foreign investment rules are among the significant element of globalization. The trend of international trade has remarkably risen since the creation of General Agreement on Tariffs and Trade (GATT), in 1948, and later replaced by World Trade Organization (WTO) in 1995 as a body for trade negotiations, policies and rules, though trade policies still favour mostly developed economies at the expense of poor nations as trade imbalances still exist.

The significant element of economic globalization is the integration and expansion of world trade and financial flows through the abolition or reduction of trade barriers such as import tariffs, quotas, and liberalized foreign investment rules. According to OECD (2008), multinational Corporations (MNCs) have been providing capital flows, the so-called FDI, which serves as a major vehicle for local enterprise development. It also helps improve the competitive position of both the receiving ("host") and the investing ("home") economy.

Part of the profits made from those investments are paid back to host countries in the form of taxes and royalties. Unarguably, the participation of MNCs in most developing nations helps to increase the internationalization of industrial production in these host countries.

International migration (movement of people across borders) has also been an integral part of the world economic system since the industrial revolution in the 19th century (Knox et al., 2008). Lately, migrants' remittances from abroad seem to be on the rise. For instance, recent data available from UNCTADSTAT (2013) showed Nigeria, among the top five recipients of remittances in the world. The country is the highest recipients in Africa with $\$ 20.57$ billion and followed by Egypt with $\$ 14.32$ billion in 2012. Migrants' remittance help in reducing poverty in many developing countries like Nigeria. The massive inflows of remittance are also contributing to the GDP growth in Nigeria (see figure 1).

Figure 1: Nigeria: Interaction of leading Globalization Indicators on Real GDP per Capita (1980 - 2012)

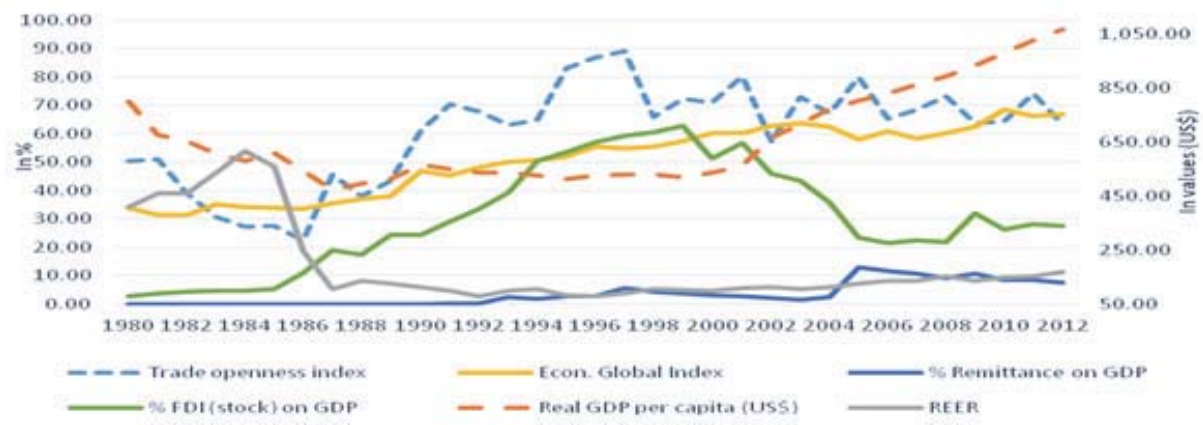

Source: Authors' Work based on UNCTADSTAT, 2013, CBN, 2013, KOF ECGI, 2013 
Similarly, statistical data available from UNCTADSTAT (2013) showed Nigeria, the highest receiver of FDI in Africa in between 2011 and 2012, which amounted to the tune of $\$ 8.9$ and $\$ 7.03$ billion respectively, and followed closely by South Africa with $\$ 6$ and $\$ 4.57$ billion in the same period. Some studies (Faruku et al., 2011; Leitao, 2012) allude to the positive relationship between FDI and economic performance of recipient economies. Nkoro and Furo (2012); Bamidele and Joseph (2013) also find a positive connection between FDI and growth in Nigeria.

Some studies provide robust evidence of a positive relationship between remittances and economic performance of developing countries (Azam and Khan, 2011; Cooray, 2012; Dilshad, 2013; Ramirez, 2014).

The KOF globalization index, a brainchild of Dreher (2006), and Dreher et al. (2008); provides a useful yardstick for measuring globalization in various countries of the world. This index consists of three key dimensions, viz: economic globalization, social globalization, and cultural globalization. For the purpose of this study, we shall only pay close attention to the economic globalization index (ECGI). This dimension of globalization comprises two categories: actual flows (trade as percent of GDP, FDI stocks as percent of GDP, portfolio investment as percent of GDP, income payments to foreign nationals as percent of GDP); and restrictions which include hidden import barriers, mean tariff rate, taxes on international trade as percent of current revenue, and capital account restrictions. Some studies (Dreher and Gaston, 2008; Leitao, 2012) find a positive relationship between the KOF economic globalization index and economic performance in countries.

\section{Implications of Economic Globalization}

Globally, economic globalization has its attendant benefits and costs. The increasing trade and connections between people and countries has not only been creating wealth in regions, but also it has been bringing global financial system risk, inequality, and costs especially to poor countries, for whom the stakes are much higher (Mackinnon and Cumbers, 2007).

There is no gainsaying the fact that difficulties that might arise in the measurement of real effective exchange rate (REER) in countries may hamper foreign trade because most countries would be favourably disposed of manipulating their exchange rates all in a bid to make their products appear more globally competitive. As stressed by Catão (2007), establishing whether a currency is undervalued or overvalued has always been problematic, just as changes in terms of trade and differences in macroeconomic policies may constitute dire consequences to trade liberalization.

Imbalances in trade agreements between developed and developing countries have made the latter to suffer the consequence. Undoubtedly, there are some asymmetries in international trade agreements, advanced economies are insisting that poor countries should remove their trade subsidies and barriers for goods which they have comparative advantage, but majority of them do not reciprocate (Stiglitz, 2003). Some of these nations are more reluctant in opening up their markets and reducing subsidy in goods and services which weak economies have advantages. As a result, global trade, in many ways, is disadvantageous to the poor nations especially in Sub-Saharan African countries (Stiglitz and Charlton, 2007).

\section{Materials and Methods}

For the purpose of this research, we mainly used secondary data: books, journals, statistical bulletins, articles and internet resources were used. This study employs annual time series data, spanning from 1980 to 2012. The time series data were extracted from three main sources - Central Bank of Nigeria (CBN) Statistical Bulletin, 2013; United Nations Conference on Trade and Development (UNCTAD) statistical reports, 2013; and the KOF Index of Globalization (Dreher, 2006; Dreher et al., 2008). Econometric tests were performed on the available datasets using both GRETL 1.9 .4 and Microfit 5.01 Software versions.

\subsection{Analytical Framework and Methodology}

We employ a modified Cobb-Douglas production function which incorporates the following exogenous variables: foreign direct investment (FDI), remittances (REMIT), real effective exchange rate (REER), trade openness (TO), and economic globalization index (ECGI) while the endogenous variable is real gross domestic product per capita(RGDPK) which is a proxy for economic performance. The general form of the estimated model is specified as follows:

$\mathrm{RGDPK}_{\mathrm{t}}=\mathrm{f}\left(\mathrm{REMIT}_{\mathrm{t}}, \mathrm{FDI}_{\mathrm{t}}, \mathrm{ECGI}_{\mathrm{t}}, \mathrm{REER}_{\mathrm{t}}, \mathrm{TO}_{\mathrm{t}}\right)$ (1)

Where; RGDPK $\mathrm{t}_{\mathrm{t}}$ is real gross domestic product per capita which is a measure of economic performance, $\mathrm{REMIT} \mathrm{T}_{\mathrm{t}}$ is remittances from Nigerians in Diaspora (proxied by remittances as \% of GDP), FDIt is foreign direct investment (proxied 
by FDI stock), ECGIt is economic globalization index (sub-index of KOF Globalization Index), REERt is real effective exchange rate (CPI based), and TOt is trade openness ((X+M) / GDP).

\subsection{Econometric Model}

Given the equation (1) above, we now respecify the model to incorporate an error term. The model is as formulated below:

$\ln R G D P K_{t}=\alpha_{0}+\alpha_{1} t+R E M I T_{t}+\ln F D I_{t}+E C G I_{t}+\ln R E E R_{t}+\ln T O_{t}+\mu_{t}$

The focus of this paper is to investigate the above stated model empirically using Autoregressive Distributed Lag (ARDL) model approach to cointegration (long-run equilibrium relationship). ARDL approach to cointegration, commonly referred to as bounds testing approach owed its roots in the works of Pesaran and Shin ((as cited in AssenmacherWesche and Pesaran, 2008) and Pesaran et al (2001]. Some researchers (Pattichis, 1999 (as cited in Afzal et al., 2013); Ghatak and Siddiki, 2001 (as cited in Sultan, 2012); Habibi and Rahim (2009); Kargbo (2012); Mall, 2013) seem to agree that the ARDL approach to cointegration yields robust results irrespective of the sample size.

As posited by Pesaran et al. (2001), variables in the model do not need to be pretested for unit root (stationarity) test so far as valid conclusion can be drawn from the bounds testing approach to cointegration. In order to investigate the short-run and long-run dynamics of the model, we now respecify equation (2) above and this is as shown below:

$$
\begin{aligned}
& \Delta \ln R G D P K_{i}=\alpha_{0}+\alpha_{1} t+\sum_{i=1}^{p} \alpha_{2} \Delta \ln R G D P K_{\ldots}+\sum_{i=1}^{p} \alpha_{3} \Delta R E M I T_{\ldots} \ldots+\sum_{i=1}^{p} \alpha_{4 i \Delta} \ln F D I_{\ldots+} \\
& +\sum_{i=1}^{p} \alpha_{s} \Delta E C G I_{\ldots-i}+\sum_{i=1}^{p} \alpha_{6} \Delta \ln \operatorname{REER}_{\ldots, i}+\sum_{i=1}^{p} \alpha_{i} \Delta \ln T O_{\ldots-i}+\beta_{1} \ln R G D P K_{\ldots-1} \\
& +\beta_{2} \text { REMIT }_{1-1}+\beta_{3} \ln F I_{1-1}+\beta_{4} E_{4} C_{1-1}+\beta_{5} \ln \text { REER }_{1-1}+\beta_{6} \ln T O_{1-1}+\varepsilon_{t}
\end{aligned}
$$

The above equation is otherwise referred to as conditional Unrestricted Error Correction Model (UECM). Where $\Delta$ are the first difference operator, $a_{0}$ denotes the constant term, $a_{1}$ is the trend, $p$ is the optimal lag length, usually chosen with the aid of an information criterion. Parameters $\left(\alpha_{2}\right.$ to $\left.\alpha_{7}\right)$ represent the short-run dynamics of the model while $\beta_{1}$ to $\beta_{6}$ are the long-run coefficients, and $\varepsilon_{i t}$ is the white-noise error term.

The next procedure is to test the null hypothesis of no cointegration as against the alternative hypothesis of the presence of cointegration using a joint significance test of the coefficients of the lagged variables using either F-statistics and/ or Walds test. That is,

$$
H_{0}=\beta_{1}=\beta_{2}=\beta_{3}=\beta_{4}=\beta_{5}=\beta_{6}=0
$$

$H_{1}=\beta_{1} \neq \beta_{2} \neq \beta_{3} \neq \beta_{4} \neq \beta_{5} \neq \beta_{6} \neq 0$

The null hypothesis of no cointegration can only be rejected for I (1) variable or a mixture of both I (0) and I (1) variables when the computed F-statistic and/or Wald test is higher than the upper bound of the critical value of the test statistic at a given significance level. The result of the cointegration test is inconclusive if the computed F-statistic (or Wald test) lies between the lower and upper bounds critical values. From the foregoing, Hendry (1995 as cited in Sheefeni, 2013) posited that equation (3) can be reparamatized as an Error Correction Model as follows:

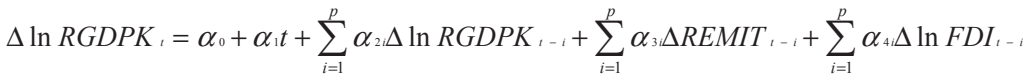

$$
\begin{aligned}
& +\sum_{i=1}^{p} \alpha_{s} \Delta E C G I_{t-i}+\sum_{i=1}^{p} \alpha_{6} \Delta \ln R E E R_{t-i}+\sum_{i=1}^{p} \alpha_{i} \Delta \ln T O_{t-i}+\varphi E C T_{t-1}+V_{t}
\end{aligned}
$$

Where $\varphi$ denotes the speed of adjustment to equilibrium after any initial disequilibria. The coefficients of the lagged variables represent the short-run dynamics of the model while ECT is the residuals that were hitherto obtained from equation (3). ECT is thus,

$$
E C T_{t}=\ln R G D P K_{t}-\delta_{1} R E M I T_{t}-\delta_{2} \ln F D I_{t}-\delta_{3} E C G I_{t}-\delta_{4} \ln R E E R_{t}-\delta_{5} \ln T O_{t}
$$

\section{Empirical Results and Discussion}

\subsection{Unit Root Test}

As can be seen from table 1, all the variables are I (1) variables. 
Table 1: Unit Root Test

\begin{tabular}{|l|l|l|l|l|l|l|}
\hline Variable & InRGDPK & REMIT & InFDI & ECGI & InREER & InTO \\
\cline { 2 - 7 } & \multicolumn{5}{|l|}{} \\
\hline Test & & & & & & \\
\hline ADF_level & -0.36 & 0.12 & -0.99 & -1.28 & -1.23 & -3.07 \\
\hline ADF_1" Diff. & $-3.76^{*}$ & $-3.98^{*}$ & $-3.89^{*}$ & $-4.25^{*}$ & $-4.70^{*}$ & $-4.50^{*}$ \\
\hline ADF-GLS_level & -1.80 & -2.81 & -1.22 & -1.51 & -1.76 & -2.02 \\
& & & & & & \\
\hline ADF-GLS_1"Diff. & $-3.61^{*}$ & $-4.12^{*}$ & $-3.97^{*}$ & $-3.64^{*}$ & $-4.56^{*}$ & $-3.25^{*}$ \\
\hline
\end{tabular}

Notes: The unit root test carried out here involves testing with both constant and trend terms.

The asterisk (*) denotes stationary at 5\% significance level.

\subsection{Test for Cointegration Analysis (F and Wald test Statistic)}

From the result (see table 2), the null hypothesis of no cointegration cannot be accepted because the computed values of both tests ( $F$ and Wald) which are 6.1149 and 36.6896 respectively are higher than the upper bound of the critical values.

Table 2: F-test and Wald-test for Cointegration Analysis

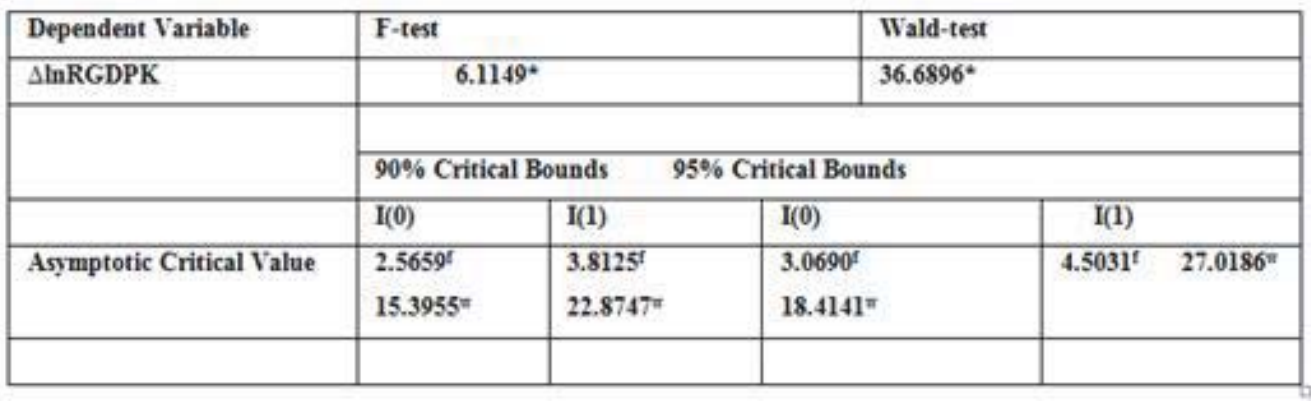

Notes: The asterisk ( $\left(^{*}\right)$ denotes a rejection of the null hypothesis of no cointegration at $5 \%$ significance level.

The superscripts ( $f$ and $w$ ) represent F-test and Wald test critical bound values while I(0) and I(1) denote lower and upper bounds respectively. The asymptotic critical values are computed by stochastic simulations using 20000 replications.

\subsection{ARDL Unrestricted Error Correction Model Estimate}

The estimate of the generalized unrestricted error correction model is as shown in table 3. The choice of ARDL model (1, $1,1,0,0$, and 0 ) selected is based on Schwarz-Bayesian Information Criterion (SIC). From the model, both the RSquared and adjusted R-Squared are $99.9 \%$. This means that the regressors can explain about $99.9 \%$ of the variation in the model within the model. The Durbin Watson test statistic of 1.95 indicates the absence of first-order autocorrelation of residuals in the model. The F-test for the model is equally significant at conventional significance levels. The model meets all specifications of the diagnostic tests (see table 4). 
Table 3: Generalized ARDL Model Estimate

\begin{tabular}{|c|c|c|c|}
\hline \multicolumn{4}{|c|}{$\begin{array}{l}\text { ARDL }(1,1,1,0,0,0) \text { selected bat } \\
\text { Dependent variable is InRGDPK }\end{array}$} \\
\hline Regressor & Coerficient & Standard Error & T-Ratio [Prob] \\
\hline InRGDPK $(-1)$ & .79792 & .085769 & $9.3031[.000]^{\cdots}$ \\
\hline REMIIT & .017255 & .0070768 & $2.4383[.023]^{\ldots}$ \\
\hline REMTI (-1) & -.021308 & .0086764 & $-2.4559[.022]^{t+}$ \\
\hline $\ln F D I$ & .94544 & .049531 & $19.0879[.000]^{+\infty}$ \\
\hline $\operatorname{InFDY}(-1)$ & -.72357 & .082736 & $-8.7456[.000]^{\cdots}$ \\
\hline ECGI & -.010184 & .0069683 & $-1.4615[.157]$ \\
\hline InREER & $.7968 \mathrm{E}-3$ & .016620 & $.047943[-962]$ \\
\hline InTo & -.10240 & .060755 & $-1.6855[.105]$ \\
\hline $\mathbf{T}$ & -.0015091 & .0097543 & $-.15471[.878]$ \\
\hline
\end{tabular}

Notes: The asterisks $\left({ }^{* * *},{ }^{* *}\right)$ denote statistical significance at $1 \%$ and $5 \%$ significance levels. The authors have deliberately omitted the drift component(constant) and included only the trend component (denoted by $\mathrm{T}$ ) based on the time series plot of the selected variables even though the result of the model as shown above indicates $T$ is statistically insignificant.

Table 4: ARDL $(1,1,1,0,0,0)$ Model Diagnostic Tests

\begin{tabular}{|c|c|c|c|}
\hline Test Statistics & LM Version [Prob] & & F Version [Prob] \\
\hline Serial Correlation & $.0074047[.931]$ & & $.0050919[.944$ \\
\hline Functional Form & $2.1561[.142]$ & & $1.5894[.221]$ \\
\hline Normality & $.77009[.680]$ & & Not Applicable \\
\hline Heteroscedasticity & $\mid .0054130[.941]$ & & $.0050756[.944]$ \\
\hline $\begin{array}{ll}\text { R-Squared } & \text { R-Bar-Squared } \\
0.99926 & 0.99900\end{array}$ & $\begin{array}{cc}\text { S.E. of Regression } & \text { RSS } \\
0.065477 & 0.098608\end{array}$ & $\begin{array}{l}\text { DWV-statistic } \\
1.9523\end{array}$ & $\begin{array}{c}\text { F-Stat. } \\
\text { F }\left(\mathbf{8 , 2 3 )} 3877.9[.000]^{*}\right.\end{array}$ \\
\hline
\end{tabular}

The asterisk $\left(^{*}\right)$ denotes statistical significance at $1 \%$ significance level.

\subsection{Estimation of Long-run Dynamics}

The results of the estimated long-run dynamics which is shown in table 5, only foreign direct investment (FDI) appears to have a long-run positive relationship with Nigeria's economic performance. The parameter estimate of FDI is statistically significant at 0.01 level with a long-run elasticity of 1.098 that is, for every $1 \%$ increase in FDI, Nigerian economic performance grows by approximately $1.10 \%$. This result is akin to the findings of some authors (Bhattacharya and Bhattacharya, 2011; Ahmad et al., 2012; Dash and Parida, 2013) on FDI-led growth hypothesis in developing economies. Arguably, the long-run positive relationship that emanates from FDI into Nigeria's economic performance can be attributed to the substantial presence of multinational corporations (MNCs) in the most critical prime sector - oil and gas sector of the country's economy. Over time, the investments made by MNCs within this sector have largely helped to fuel Nigeria's economic performance.

Table 5: Estimated long-run Dynamics of Economic Performance (RGDPK)

Estimated Long Run Coefficients using the ARDL Approach
ARDL (1, 1, 1, 0, 0, 0) selected based on Schwarz Bayesian Criterion
Dependent variable is InRGDPK
\begin{tabular}{|l|l|l|l|}
\hline \multicolumn{4}{|c|}{} \\
\hline Regressor & Coefficient & Standard Error & T-Ratio [Prob] \\
\hline REMIT & -.020056 & .052548 & $-.38167[.706]$ \\
\hline InFDI & $1.0979^{* * *}$ & .21129 & $5.1964[.000]$ \\
\hline ECGI & $-.050395^{*}$ & .029202 & $-1.7257[.098]$ \\
\hline InREER & .0039430 & .081961 & $.048109[.962]$ \\
\hline InTO & -.50674 & .41995 & $-1.2067[.240]$ \\
\hline T & -.0074675 & .047382 & $-.15760[.876]$ \\
\hline
\end{tabular}

Note: The asterisks ( ${ }^{* \star *},{ }^{*}$, and $*$ ) denote significance at $1 \%, 5 \%$ and $10 \%$ respectively 
Rather unexpectedly, KOF economic globalization index (ECGI) appears to be negatively associated with long-term economic performance, and it is statistically significant at the 0.1 level. It shows that for every $1 \%$ percentage point rise in the KOF ECGI scores, it depletes economic performance by approximately $5 \%$. From a theoretical perspective, this might seem absurd, but it is very plausible that there are some unique and country-specific underlying factors (trade policy somersault, dearth of critical infrastructure, weak institutional frameworks, low technological base, and manufacturing capacity underutilization) which are not captured from this KOF dimension of globalization. Hence, the negative impact on economic performance as captured by RGDPK.

In a way, this result complements the findings of Bergh and Therese (2010); they did report a positive statistical relationship that stems from the ECGI to inequality using a cross-country panel data analysis of 80 countries. Unarguably, income inequality remains an albatross to economic performance not only in Nigeria but also within the globe. However, remittances, real effective exchange rate and trade openness including the trend component estimate were all statistically insignificant. Even though trade openness is statistically insignificant, it appears to have a negative relationship with economic performance. The negative relationship between trade openness and economic performance is in line with the findings between the KOF ECGI and economic performance.

\subsection{Estimation of Short-run Dynamics}

Table 6 depicts the short-run estimated model. The estimated coefficient of the lagged error correction term - ECM (-1) has the expected negative sign, and it is also statistically significant at 0.05 level. The speed of adjustment is relatively low, and it shows that only about $20.2 \%$ of the disequilibrium within the model in the previous year is subsequently corrected in the current year.

The speed of adjustment of the variables in the model in response to a deviation from its long-run equilibrium path is $20.2 \%$. The result of the error correction term provides strong evidence that there is indeed a long-run equilibrium relationship between the exogenous variables (REMIT, FDI, ECGI, REER, and TO) and RGDPK which is a proxy for economic performance. Similar to the long-run equation, FDI was also found to foster economic performance, and it is statistically significant at the 0.01 level. This result is consistent with the findings of some similar empirical works (Osinubi and Amaghionyeodiwe, 2010; Adhikary, 2011; and Insah, 2013).

Table 6: Estimates of Short-run Dynamics of Economic Performance (RGDPK)

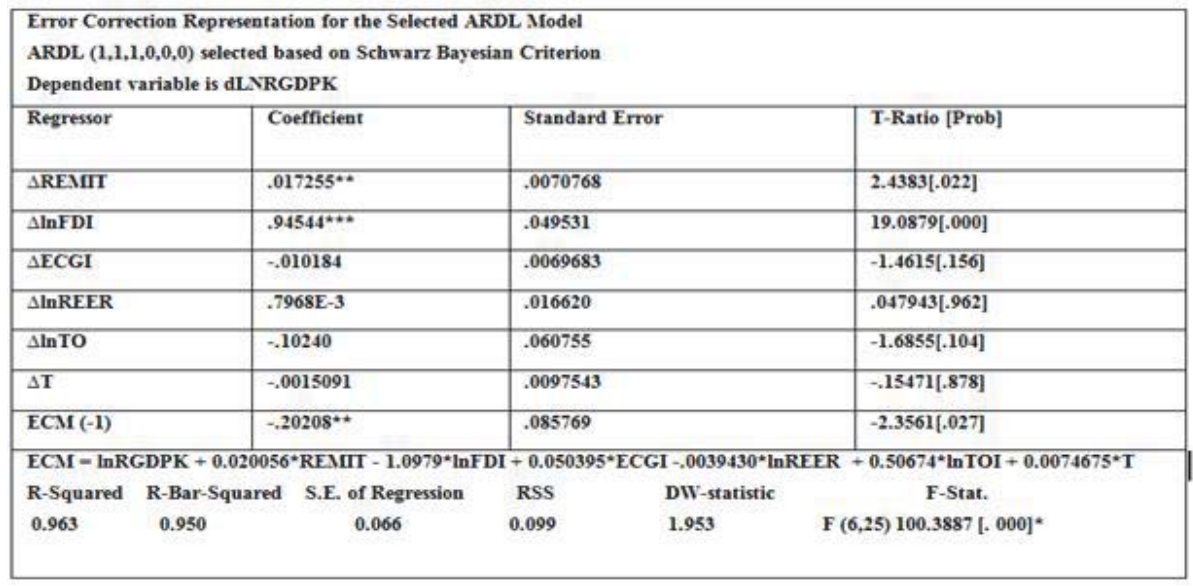

Note: The asterisks $\left({ }^{* *},{ }^{* *}\right.$, and $*$ ) denote significance at $1 \%, 5 \%$ and $10 \%$ respectively

In the same vein, the inflow of remittances from Nigerians in Diaspora was found to be positively associated with economic performance. It is statistically significant at 0.05 level, and it shows that a $1 \%$ percentage point increase in remittances from abroad as a proportion of GDP spurs economic performance by $0.02 \%$. Some recent studies (Dilshad, 2013; Driffield and Jones, 2013; Ukeje and Obiechina, 2013 and Azam et al., 2013) have equally brought to the fore, the short-term positive effect that flows from REMIT to RGDPK (proxy for economic performance) in a few developing countries.

On the other hand, both the KOF economic globalization index and trade openness were found to be negatively 
correlated with economic performance and at the same time statistically insignificant. Even though the coefficient of REER is positive, there is no contemporaneous impact of the change in REER in economic performance since it was also found to be statistically insignificant. By and large, the short-run dynamics seem to have a good model fit with about $96 \%$ of the variation fully captured within the model. Note also that the model is devoid of any serial autocorrelation (see table).

\subsection{Estimated Model Stability Diagnostics}

As a confirmation of the estimated model stability, the plots of both CUSUM and CUSUMSQ are as shown in figures 2 and 3 respectively. We can infer from the plots that the long-run coefficients are stable since they are all fall within the critical bands at 0.05 level. Also, see appendix B for a plot of actual and fitted values of the proxy for economic performance (InRGDPK).

Figure 2: CUSUM Plot of Parameter Stability Test

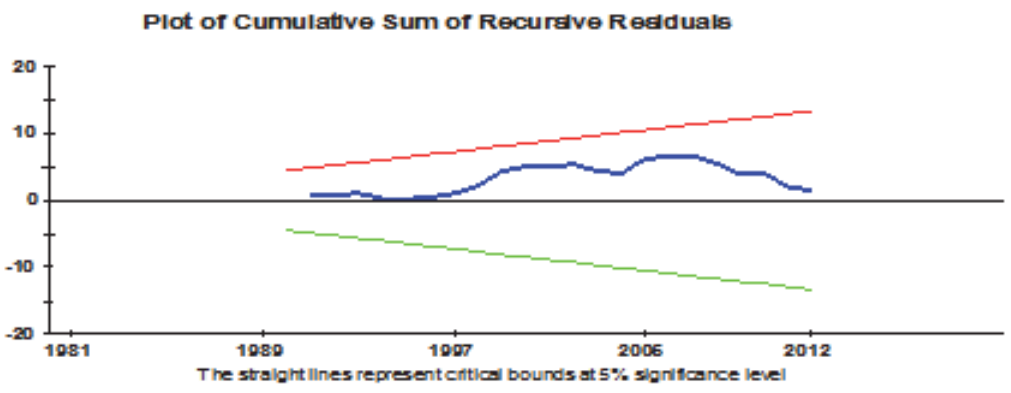

Figure 3: Plot of CUSUMSQ Parameter Stability Test

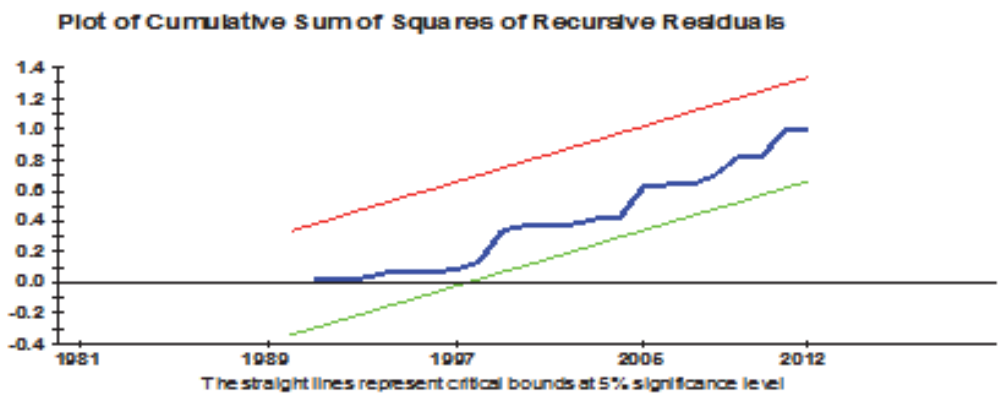

\section{Conclusion and Policy Direction}

The main objective of this article was to analyze the relationship between some leading indicators of economic globalization (e.g. FDI, migrants' remittances and, REER) and economic performance in Nigeria for the past three decades. The empirical results of this study provide strong evidence that FDI has the catalytic effect of spurring economic performance both within the short-run and long run in Nigeria.

International migrants' remittances augment economic performance in the short-run. This could be adduced to the fact that remittances are usually not stable and served mainly as palliative measures to cushion short-term economic shocks in the Nigerian domestic economy.

Based on the model estimate, it was discovered that the KOF dimension of economic globalization has an adverse effect on long-run economic performance in Nigeria. Also, other findings show that real effective exchange rate and trade openness do not add up in the both the short-run and long-run that is, they neither improve nor deteriorate economic performance.

Going forward, policy and decision makers in Nigeria should endeavour to not only initiate, but also implement robust and scalable macroeconomic policies that would be attractive to foreign investors as well as position the country as a globally competitive marketplace for national development. More so, government at all levels should make concerted 
efforts in partnering with Nigerians in Diaspora so that they could invest more in the country, most especially in critical infrastructure projects such as housing, medical facilities, educational facilities, and transportation.

Lastly, and most importantly, it is very pertinent to state that as much as economic globalization or globalization within its widest context is indispensable, the slogan "Think globally, and act locally" should be the key to translating economic performance into inclusive and sustainable economic development in Nigeria.

\section{References}

Adhikary, B. K. (2011). FDI, trade openness, capital formation, and economic growth in Bangladesh: A linkage analysis. International Journal of Business and Management, 6(1), 16-28.

Afzal et al. (2013). Openness, inflation and growth relationships in Pakistan: an application of ARDL bounds testing approach. Pakistan Economic and Social Review, 51(1), 13-53.

Ahmad et al. (2012). The causal links between foreign direct investment and economic growth in Pakistan. European Journal of Business and Economics, 6, 20-21.

Ajayi, F. O., \& Atanda, A. A. (2012). Globalization and macroeconomic stability in Nigeria: An autoregressive adjustment analyses. European Journal of Globalization and Development Research, 3(1).

Assenmacher-Wesche, K., \& Pesaran, M. H. (2008). A VECX* model of the Swiss economy: Empirical and theoretical methods (Working Paper NO. 2281). CESIFO, 10.

Azam, M., Hassan, S., \& Khairuzzaman. (2013). Corruption, workers remittances, FDI and economic growth in five South and South East Asian countries: a panel data approach. Middle-East Journal of Scientific Research, 15(2), 184-190.

Azam, M., \& Khan, A. (2011). Workers' remittances and economic growth: evidence from Azerbaijan and Armenia. Global Journal of Human Social science, 11(7), 41-46.

Baluch, K. A., Bukhari, S. A. H. (2012). Price and income elasticity of imports: The case of Pakistan (SBP Working Paper Series 48). Retrieved from SBP web: http://www.sbp.org.pk/publications/wpapers/index2.asp.

Bamidele, T.B., \& Joseph, A.I. (2013). Financial crisis and external debt management in Nigeria. International Journal of Business and Behavioral Sciences, 3 (4), 16-28.

Bhattacharya, M., \& Bhattacharya, S.N. (2011). The interrelationship between merchandise trade, economic growth and FDI inflows in India. South-Eastern Europe Journal of Economics, 2, 229-244. [Online]. Available at: http:///bit.ly/1cyW2HU. [Accessed on 1 November 2013].

Bergh, A., \& Nilsson, T. (2010). Do liberalization and globalization increase income Inequality? European Journal of Political Economy, $26(4), 488-505$.

Catão, L. A.V. (2007). Why real exchange rates? Finance and development. International Monetary Fund, 44(3), 46-47.

Central Bank of Nigeria. (2013). Statistical bulletin. Retrieved from CBN website: http://www.cenbank.org/documents/Statbulletin.asp.

Cooray, A. V. (2012). The impact of migrant remittances on economic growth: evidence from South Asia. Review of International Economics, 20(5), 985-998.

Crafts, N. (2004). Globalization and economic growth: a historical perspective. The World Economy, 27(1), 45-58.

Dash, R. K., \& Parida, P. C. (2013). FDI, services trade and economic growth in India: empirical evidence on causal links. Empirical Economics, 45(1), 217-238.

Dilshad, W. B. (2013). Impact of workers' remittances on economic growth: an empirical study of Pakistan's economy. International Journal of Business and Management, 8(24), 126-131.

Dreher, A. (2006). Does globalization affect growth? Evidence from a new index of globalization. Applied Economics, 38(10), 10911110.

Dreher, A., Gaston, N. and Martens, P. (2008). Measuring globalisation: Gauging its consequences. New York, NY: Springer.

Driffield, N., \& Jones, C. (2013). Impact of FDI, ODA and migrant remittances on economic growth in developing countries: A systems approach. European Journal of Development Research, 25(2), 173-196.

Faruku et al. (2011). Causality analysis of the impact of foreign direct investment on GDP in Nigeria. Nigerian Journal of Basic and Applied Science, 19(1), 9- 20.

Habibi, F., \& Rahim, K.A. (2009). A bound test approach to cointegration of tourism demand. American Journal of Applied Sciences, 6(11), 1924-1931.

International Monetary Fund (IMF). 2008. Globalization: A Brief overview, IMF issues brief, issue 02/08. [Online]. Available at: http:///bit.ly/IUW2UW. [Accessed: 25. March 2013].

Insah, B. (2013). Foreign direct investment inflows and economic growth in Ghana. International Journal of Economic Practices and Theories, 3(2), 115-121.

Kargbo, P. M. (2012). Impact of foreign aid on economic growth in Sierra Leone: empirical analysis (Working Paper No. 2012/07). Retrieved from UNU-WIDER: http://www.wider.unu.edu/publications/working-papers/2012/en_GB/wp2012-007/

Knox, P., Agnew, J. and Mccarthy, L. (2008). The geography of the world economy (5th Ed.). London: Hodder Education.

Leitao, N. C. (2012). Economic growth, globalization and trade. Management Research and Practice, 4(3), 18-24.

Loto, M.A. (2011). Globalization and economic development: the Nigerian experience and prospects 1980 - 2008. JETEMS, 2(3), 160167. 
Mall, S. (2013). Foreign direct investment inflows in Pakistan: a time series analysis with autoregressive distributed lag (ARDL) approach. International Journal of Computer Applications, 78(5), 7-16.

Nkoro, E., \& Furo, A.O. (2012). Foreign capital inflows and economic growth in Nigeria: an empirical approach. Academic Journal of Interdisciplinary Studies, 1 (2), 55-71.

Ocampo, J. A. and Martin, J. (2003). Globalization and development: A Latin American and Caribbean Perspective. Stanford, CA: Stanford University Press.

OECD (2008). Benchmark definition of foreign direct investment (4th Ed.). Paris: OECD Publishing.

Osabuohien, E.S.C. (2007). Globalization, governance, and economic growth in West Africa: The Case of Cote d' Ivoire and Nigeria. Journal of Economic Thought, 2(1).

Osinubi, T. S., \& Amaghionyeodiwe, L. A. (2010). Foreign private investment and economic growth in Nigeria. REBS, 3(1), 105-127.

Pesaran, M. H., Shin, Y., \& Smith, R. J. (2001). Bounds testing approaches to the analysis of long run relationship. Journal of Applied Econometrics, 16, 289-326.

Ramirez, M. D. (2014). Remittances and economic growth in Mexico: An empirical study with structural breaks. Business and Economic Research, 4(1), 351-371.

Sheefeni, J. P. S. (2013). Demand for money in Namibia: an ARDL bounds testing approach. Asian Journal of Business and Management, 1(3), 65-71.

STiglitz, J. E. (2003). The future of globalization: Lessons from Cancun and resent financial crisis. In. Proceedings of the International Conference on the Future of Globalization. Yale Centre for the Study of Globalization, 10-11 October. New Have: Yale Law School, Yale Centre for the Study of Globalization, 71-81.

Stiglitz, J. E. and Charlton, A. (2007). Fair trade for all: How trade can promote development. New York: Oxford University Press.

Sultan, R. (2012). An econometric study of economic growth, energy and exports in Mauritius: Implications for trade and climate Policy. International Journal of Energy Economics and Policy, 2(4), 225-237.

Todaro, M. P. and Smith, S. C. (2011). Economic Development. (11th Ed.). Pearson Education and Addison-Wesley.

Ukeje, E. U. and Obiechina, M. E. (2013). Workers' remittances - economic growth nexus: Evidence from Nigeria, using an error correction methodology. International Journal of Humanities and Social Science, 3(7), 212-227.

UNCTADSTAT (2013). World statistical database. Geneva: United Nations.

Walter, R. (1972). How Europe underdeveloped Africa. London: Bogle-L'ouverture Publications. 